\title{
Dietary assessment of women surviving breast cancer according to the Dietary Guidelines for the Brazilian Population
}

\author{
Avaliação dietética de mulheres Sobreviventes de \\ Câncer de mama segundo as orientações do \\ Guia Alimentar para a População Brasileira
}

\author{
Patrícia Cândido ALVES1 (iD) 0000-0002-2113-7423 \\ Helena Alves de Carvalho SAMPAIO ${ }^{1}$ (D) 0000-0001-5353-8259 \\ Eliane Mara Viana HENRIQUES1 (iD) 0000-0002-7968-9917 \\ Soraia Pinheiro Machado ARRUDA ${ }^{1}$ iD 0000-0002-3918-4738 \\ Antônio Augusto Ferreira CARIOCA² ID 0000-0002-1194-562X
}

A B S T R A C T

\section{Objective}

Review the diet and nutritional status of women surviving breast cancer following the Dietary Guidelines for the Brazilian Population.

\section{Methods}

A cross-sectional study was conducted with 201 women, who underwent anthropometric measurements to determine body mass index, waist circumference and waist/hip ratio. Dietary assessment was performed using a food frequency questionnaire. Consumption was stratified into four groups: fresh/minimally processed food (Group 1), processed food ingredients (Group 2), processed food (Group 3) and ultra-processed food (Group

\footnotetext{
${ }^{1}$ Universidade Estadual do Ceará, Centro de Ciências da Saúde, Programa de Pós-Graduação em Saúde Coletiva. Av. Dr. Silas Munguba, 1700, Campus do Itaperi, 60741-000, Fortaleza, CE, Brasil. Correspondence to: HAC SAMPAIO. E-mail: <dr.hard2@gmail.com>.

2 Universidade de Fortaleza, Centro de Ciências da Saúde, Programa de Pós-Graduação em Saúde Coletiva. Fortaleza, CE, Brasil.

Article based on the dissertation of PC ALVES, intitled "Avaliação dietética de mulheres sobreviventes de câncer de mama segundo as orientações do Guia Alimentar para a População Brasileira”. Universidade Estadual do Ceará; 2019.
}

How to cite this article

Alves PC, Sampaio HAC, Henriques EMV, Arruda SPM, Carioca AAF. Dietary assessment of women surviving breast cancer according to the Dietary Guidelines for the Brazilian Population. Rev Nutr. 2019;32:e190054. http://dx.doi. org/10.1590/1678-9 865201932e190054 
4). The ratio of daily contribution of each food group to total calories and macronutrients supply was calculated. Statistical analysis was performed using Chi-square tests and Spearman correlation, with $p<0.05$ as significance level.

\section{Results}

The mean age was $50 \pm 11$ years. An abdominal fat accumulation with a high excess weight condition in women under 60 years of age $(p=0.003)$ was observed. A greater intake of group 1 food, but contributing with about $1 / 3$ of the calories and macronutrients total intake as compared to food groups 3 and 4 was also observed.

\section{Conclusion}

The women assessed consumed a higher proportion of calories and macronutrients from fresh/minimally processed food. There is no theoretical reference that allows to affirm that the amount of processed and ultra-processed food consumed represents a health hazard for those women. There was no association between dietary intake, nutritional status and age group.

Keywords: Breast neoplasms. Cancer survivors. Food guide. Healthy diet.

\section{RE S U M O}

\section{Objetivo}

Analisar dieta e estado nutricional de mulheres sobreviventes de câncer de mama com as orientações do Guia Alimentar para a População Brasileira.

\section{Métodos}

Estudo transversal, com 201 mulheres, que realizaram exames antropométricos, para determinação de índice de massa corporal, circunferência da cintura e relação cintura/quadril. A avaliação dietética foi realizada por questionário de frequência alimentar. O consumo foi estratificado em quatro grupos: alimentos in natural minimamente processados (Grupo 1), ingredientes culinários processados (Grupo 2), alimentos processados (Grupo 3) e alimentos ultraprocessados (Grupo 4). Calculou-se a proporção de contribuição diária de cada grupo em relação às calorias e macronutrientes. A análise estatística foi realizada por meio dos testes Qui-quadrado e correlação de Spearman, com p<0,05 como nível de significância.

\section{Resultados}

A média de idade foi de $50 \pm 11$ anos. Houve acúmulo de gordura abdominal com proporção de excesso de peso maior em mulheres menores de 60 anos $(p=0,003)$. Houve maior consumo de alimentos do Grupo 1, mas com cerca de 1/3 da contribuição calórica e de macronutrientes obtidas dos grupos 3 e 4.

\section{Conclusão}

As mulheres avaliadas consomem uma alimentação com maior proporção calórica e de macronutrientes provenientes do grupo de alimentos in natura/minimamente processados. Não há referencial teórico que permita afirmar se a quantidade de processados e ultraprocessados consumida representa risco à saúde destas mulheres. Não houve associação entre consumo alimentar, estado nutricional e faixa etária.

Palavras-chave: Neoplasias da mama. Sobreviventes de câncer. Guias alimentares. Dieta saudável.

\section{NTRODUCTION}

Breast cancer accounts for about 28\% of new cancer cases each year. In Brazil, 59,700 new cases of breast cancer are estimated to develop in each year of the 2018-2019 biennium [1]. Risk factors include inadequate diet and overweight [2]. Obesity causes an increased risk of breast cancer due to high concentration of insulin, sex hormones and inflammation, and may negatively affect cancer survival, quality of life, disease recurrence and mortality [3].

Dietary assessment aiming at identifying risk factors for the onset of breast cancer and/or its recurrence has been studied more intensely over the last two decades, leading to the development 
of preventive guidelines for both the onset of breast cancer and the disease recurrence. However, there are still several queries about the exact contribution of different components present in food in reducing or increasing the risk for the disease. Additionally, there are unclear controversial aspects regarding nutritional status, such as premenopause or postmenopause interaction [2].

On the other hand, despite studies and discussions on the interrelationship between nutrition and breast cancer, the focus has not yet been specifically targeted at compliance with the guidelines provided by the Guia Alimentar para a População Brasileira (GAPB, Dietary Guidelines for the Brazilian Population), which is in its second edition [4]. In this second version a new proposal for food classification was introduced, which highlights the importance of the degree of processing as a benchmark for a healthy diet and disease prevention.

Thus, the GAPB addresses the importance of a diet based on fresh or minimally processed foods, free of chemical additives and industrialized products that should provide health benefits, controlling chronic diseases such as cancer and its relapse. In addition, the GAPB recommends limiting the intake of processed foods and avoiding ultra-processed foods [4]. Current data confirm a relationship between a major ultra-processed food intake and all cancers hazard, including breast cancer [5].

Subsequently, a new food classification was proposed: the NOVA [6], that classified food into: fresh/minimally processed, processed culinary ingredients, processed food and ultra-processed food. In contrast the World Cancer Research Fund/American Institute for Cancer Research (WCRF/AICR) [2] does not establish the same food stratification, but advocates limiting the consumption of fast food and processed food that are high in fat, starch or sugar.

Considering the importance of breast cancer from an epidemiological point of view, and the absence of this type of dietary review in this population group, the objective of this investigation was to analyze the diet (according to the Dietary Guidelines for the Brazilian Population) and the nutritional status of women surviving breast cancer.

\section{METHODS}

This is a cross-sectional study, conducted at the Regional Integrated Center of Oncology, located in Fortaleza, Ceará. The study population included women who survived breast cancer and who are undergoing treatment at the Center. The term breast cancer survivor follows the description of the WCRF/AICR [2] for cancer survivors in general, which sets forth that the term covers breast cancer survivors, from diagnosis to treatment and extending to the end of life.

This was a convenience sample that included 201 women. Female patients over 18 years of age and with breast cancer were enrolled, but those who had already been diagnosed with psychiatric and/or neurodegenerative disease and who were using medication that impaired cognition were excluded. Data collection was performed from March to November 2017.

Participants were interviewed to fill out a semi-structured data survey instrument, consisting of demographic, socioeconomic cultural and health variables and the Food Frequency Questionnaire (FFQ), validated for the Brazilian population [7], for dietary evaluation. Anthropometry was performed, measuring weight, height, waist circumference and hip circumference.

Weight and height were measured using a mechanical anthropometric scale, Filizola brand, São Paulo - Brazil, with $150 \mathrm{~kg}$ capacity and sensitivity of $100 \mathrm{~g}$. Waist and hip circumferences were 
measured with an inelastic measuring tape, Sanny brand, São Paulo - Brazil, with a length of $2.0 \mathrm{~m}$ with $0.5 \mathrm{~cm}$ sensitivity and scale division in millimeters, flexible, facilitating the adjustment of the tape to the body. The measurement protocol followed Norton\&Olds [8] guidelines for weight and height measurement, and for waist and hip circumference measurement.

The nutritional status of the patients was classified according to Body Mass Index - (BMI) $\left(\mathrm{kg} / \mathrm{m}^{2}\right)$. If $<60$ years old, the parameter adopted was the World Health Organization's (WHO) $[9,10]$. The classification included: Underweight $\left(\mathrm{BMI}<18.50 \mathrm{~kg} / \mathrm{m}^{2}\right)$; Eutrophy $\left(\mathrm{BMI} 18.50-24.99 \mathrm{Kg} / \mathrm{m}^{2}\right)$; Overweight or Pre-obesity (BMI $25.00-29.99 \mathrm{~kg} / \mathrm{m}^{2}$ ); and Obesity $\left(\mathrm{BMI} \geq 30.00 \mathrm{~kg} / \mathrm{m}^{2}\right.$ ). Although the WHO [10] sets forth three degrees of obesity, for the present study, all cases of obesity were grouped under the title obesity. For elderly patients ( $\geq 60$ years old), the classification parameter used was that of the Pan American Health Organization [11]: Underweight (BMI $\leq 23.00 \mathrm{~kg} / \mathrm{m}^{2}$ ); Appropriate weight (BMl $>23.00$ and $\left.<28.00 \mathrm{~kg} / \mathrm{m}^{2}\right)$; Pre-obesity (BMI $\geq 28.00$ and $\left.<30.00 \mathrm{~kg} / \mathrm{m}^{2}\right)$ and Obesity (BMI $\left.\geq 30.00 \mathrm{~kg} / \mathrm{m}^{2}\right)$.

Waist Circumference (WC) and Waist Circumference/Hip circumference (WHR) ratio were measured in order to estimate abdominal fat accumulation, defined as a WC greater than or equal to $80 \mathrm{~cm}$, and an RCQ greater than or equal to 0.85 ; such cutoff points were adopted here because they are endorsed in the last WCRF/AICR report [2].

The FFQ included 102 food items [7]; the data were transformed into grams or milliliters of daily consumption, using a standardized table (Individual Food Intake Analysis in Brazil - Household Budget Survey, HBS 2008-2009) [12]. Calorie and macronutrient diet composition was determined using the United States Department of Agriculture (USDA) table.

The foods consumed were stratified into 4 groups: fresh/minimally processed food (Group 1), processed culinary ingredients (Group 2), processed food (Group 3) and ultra-processed food (Group 4) according to the NOVA food classification [6] set forth in the GAPB. The proportion of the daily intake contribution of each of the 4 groups in relation to calories and macronutrients (protein, lipids and carbohydrates) was calculated.

Statistical analysis of the data was performed using the IBM $^{\circledR}$ SPSS ${ }^{\circledR}$ (software, version 22.0 (Chicago - United States). For the anthropometric variables evaluation, the Chi-square test was used. Considering the scope of the study, for the purpose of statistical analysis the BMI variable was dichotomized into overweight and no overweight, since overweight is associated with the risk of relapse. The Spearman correlation test was used to review association between anthropometric variables, food intake and patient's age.

The study was designed according to Resolution 466/2012 of the National Health Council and approved by the Research Ethics Committee of the Institution responsible for carrying out the study (CAAE - 59485816.9.1001.5078). All participants signed an informed consent form to participate in the investigation.

\section{RE S U L T S}

Table 1 shows the demographic, socioeconomic, lifestyle and health characterization of the female patients assessed. The lower proportion of women aged 18 to 35 years (6.9\%) should be observed. The average age was $50 \pm 11$ years. Most of the interviewees went through 11 years of schooling (77.6\%), predominantly up to 8 years education (46.8\%). Also predominant were patients on sick leave and retirees (58.2\%), with family income up to 2 minimum monthly wages $(76.6 \%)$ and 
Table 1. Characterization of assessed women with breast cancer $(n=201)$. Fortaleza (CE), 2018.

\begin{tabular}{|c|c|c|}
\hline \multirow{2}{*}{ Variables } & \multicolumn{2}{|c|}{ Patients } \\
\hline & $n$ & $\%$ \\
\hline \multicolumn{3}{|l|}{ Age (years) } \\
\hline $18-35$ & 14 & 6.9 \\
\hline $35-45$ & 47 & 23.4 \\
\hline $45-60$ & 97 & 48.3 \\
\hline$\geq 60$ & 43 & 21.4 \\
\hline \multicolumn{3}{|l|}{ Schooling (years) } \\
\hline$\leq 8$ & 94 & 46.8 \\
\hline $9-11$ & 62 & 30.8 \\
\hline$\geq 12$ & 45 & 22.4 \\
\hline \multicolumn{3}{|l|}{ Work Situation } \\
\hline Paid / Self Employed Work & 37 & 18.4 \\
\hline Home chores & 47 & 23.4 \\
\hline Sick out & 70 & 34.8 \\
\hline Retired/Pensioner & 47 & 23.4 \\
\hline \multicolumn{3}{|c|}{ Family Income (minimum wage) ${ }^{1}$} \\
\hline$\leq 1$ & 83 & 41.3 \\
\hline $1-2$ & 71 & 35.3 \\
\hline $2-3$ & 28 & 13.9 \\
\hline$>3$ & 19 & 9.5 \\
\hline \multicolumn{3}{|l|}{ Marital Status } \\
\hline Married & 105 & 52.2 \\
\hline Single & 96 & 47.8 \\
\hline \multicolumn{3}{|l|}{ Smoking } \\
\hline Yes & 7 & 3.5 \\
\hline No & 194 & 96.5 \\
\hline \multicolumn{3}{|l|}{ Alcoholism } \\
\hline Yes & 5 & 2.5 \\
\hline No & 196 & 97.5 \\
\hline \multicolumn{3}{|l|}{ Diagnosis' Clinical Staging } \\
\hline । & 14 & 6.9 \\
\hline ॥ & 78 & 38.8 \\
\hline III & 92 & 45.7 \\
\hline IV & 11 & 5.4 \\
\hline Not informed & 6 & 3.0 \\
\hline \multicolumn{3}{|c|}{ Morbidities $^{\mathbf{2}}$ (other than cancer) } \\
\hline None & 133 & 60.2 \\
\hline Arterial hypertension & 45 & 20.4 \\
\hline Diabetes Mellitus type 2 & 10 & 4.5 \\
\hline Dyslipidemia & 9 & 4.1 \\
\hline Depression or Anxiety & 8 & 3.6 \\
\hline Thyroid diseases & 5 & 2.2 \\
\hline Cardiac disorders & 4 & 1.8 \\
\hline Other ${ }^{3}$ & 7 & 3.2 \\
\hline
\end{tabular}

Note: ${ }^{1}$ Minimum wage at the time of data collection: $\mathrm{R} \$ 937,00 .{ }^{2}$ Morbidities: refers to the number of morbidities reported. ${ }^{3}$ Others: Asthma (3); Chronic renal failure (1); Gastroesophageal reflux (1); Labyrinthitis (1); Back disorders (1). 
married (52.2\%). The monthly family income was $R \$ 1,719.58 \pm 1,427.75$. Smoking and alcoholism incidence was low, respectively $3.5 \%$ and $2.5 \%$. The majority $(60.2 \%)$ of the patients had no morbidities other than breast cancer. Hypertension was among the other diseases reported (20.4\%). Most of the patients had cancer stage III (45.7\%).

Regarding anthropometric data, the patients assessed had an average weight of $68.18 \pm 14.59 \mathrm{~kg}$, and an average body mass index of $28.46 \pm 5.56 \mathrm{~kg} / \mathrm{m}^{2}$. Regarding the $\mathrm{WC}, 79.6 \%$ had waist circumference $\geq 80 \mathrm{~cm}$; and $64.2 \%$ had a WHR $\geq 0.85$, indicating accumulation of abdominal fat. Table 2 shows the findings, stratified by age group, indicating a higher proportion of overweight (pre-obesity + obesity) among women under 60 years of age $(p=0.003)$, but both age groups exhibited high WC and WHR measurements, with no difference between them.

Food intake stratified according to the degree of food processing is shown in Table 3 for patients under 60 years of age, and in Table 4 for patients aged 60 and over; patients showed similar

Table 2. Distribution of women surviving breast cancer assessed according to anthropometric variables and age range. Fortaleza (CE), 2018.

\begin{tabular}{|c|c|c|c|c|c|}
\hline \multirow{2}{*}{ Anthropometric variable } & \multicolumn{2}{|c|}{$<60$ years $(n=158)$} & \multicolumn{2}{|c|}{$\geq 60$ years $(n=43)$} & \multirow{2}{*}{$p$-value ${ }^{1}$} \\
\hline & $\mathrm{n}$ & $\%$ & $n$ & $\%$ & \\
\hline \multicolumn{6}{|l|}{$I M C^{2}$} \\
\hline Thinness & 3 & 1.90 & 7 & 16.28 & 0.003 \\
\hline Eutrophy & 41 & 25.95 & 16 & 37.21 & \\
\hline Pre-obesity & 65 & 41.14 & 3 & 6.98 & \\
\hline Obesity & 49 & 31.01 & 17 & 39.53 & \\
\hline \multicolumn{6}{|l|}{$W C^{3}$} \\
\hline Proper & 34 & 21.52 & 7 & 16.28 & 0.450 \\
\hline High & 124 & 78.48 & 36 & 83.72 & \\
\hline \multicolumn{6}{|l|}{$W H R^{3}$} \\
\hline Proper & 60 & 37.98 & 12 & 27.91 & 0.222 \\
\hline High & 98 & 62.03 & 31 & 72.09 & \\
\hline
\end{tabular}

Note: ${ }^{1}$ Chi-square Test, $p<0.05$ with significance level; ${ }^{2}$ According to World Health Organization $[9,10]$ for $<60$ years and Organización Pan-Americana de la Salud [11] for $\geq 60$ years. Standardized category nomenclature for both groups and degree of obesity grouped into obesity ${ }^{3}$ According to World Cancer Research Fund/American Institute for Cancer Research [2]. BMI: Body Mass Index; CC: Waist Circumference; WHR: Waist/Hip Ratio.

Table 3. Average food consumption (with standard deviation) of assessed women under $60(n=158)$, according to the degree of food processing ${ }^{1}$ and food caloric and macronutrient contribution. Fortaleza (CE), 2018

\begin{tabular}{|c|c|c|c|c|c|c|c|c|c|c|c|c|}
\hline \multirow{2}{*}{$\begin{array}{l}\text { Food } \\
\text { processing }\end{array}$} & \multicolumn{3}{|c|}{ Calories (kcal) } & \multicolumn{3}{|c|}{ Carbohydrates (g) } & \multicolumn{3}{|c|}{ Proteins (g) } & \multicolumn{3}{|c|}{ Lipids (g) } \\
\hline & Average & SD & $\%$ & Average & SD & $\%$ & Average & SD & $\%$ & Average & SD & $\%$ \\
\hline Total & $2,228.2$ & 824.2 & & 313.3 & 130.8 & & 109.9 & 42.1 & & 63.3 & 30.9 & \\
\hline Group 1 & $1,406.1$ & 542.3 & 65.0 & 193.0 & 92.3 & 63.7 & 87.0 & 37.3 & 79.4 & 34.7 & 19.0 & 57.0 \\
\hline Group 2 & 50.7 & 49.3 & 2.5 & 4.9 & 4.7 & 1.8 & 0.0 & 0.0 & 0.0 & 3.7 & 5.5 & 5.9 \\
\hline Group 3 & 420.2 & 285.5 & 18.7 & 60.0 & 48.3 & 19.0 & 16.7 & 11.2 & 15.4 & 12.0 & 8.3 & 19.0 \\
\hline Group 4 & 349.9 & 393.9 & 14.2 & 54.8 & 70.1 & 15.5 & 5.6 & 6.8 & 4.9 & 12.9 & 15.5 & 18.0 \\
\hline
\end{tabular}

Note: ${ }^{1}$ Group 1: Fresh/minimally processed food; Group 2: Processed Cooking Ingredients; Group 3: Processed Food; Group 4: Ultra-Processed Food (according to Brasil [4]; Monteiro et al. [6]. SD: Standard Deviation. 
Table 4. Average food consumption (with standard deviation) of assessed women aged 60 and over $(n=43)$, according to the degree of food processing ${ }^{1}$ and food caloric and macronutrient contribution. Fortaleza (CE), 2018.

\begin{tabular}{|c|c|c|c|c|c|c|c|c|c|c|c|c|}
\hline \multirow{2}{*}{$\begin{array}{l}\text { Food } \\
\text { processing }\end{array}$} & \multicolumn{3}{|c|}{ Calories (kcal) } & \multicolumn{3}{|c|}{ Carbohydrates (g) } & \multicolumn{3}{|c|}{ Proteins (g) } & \multicolumn{3}{|c|}{ Lipids (g) } \\
\hline & AVG & SD & $\%$ & AVG & SD & $\%$ & AVG & SD & $\%$ & AVG & SD & $\%$ \\
\hline Total & $1,866.3$ & 661.4 & & 262.4 & 110.9 & & 97 & 38.4 & & 51.3 & 22.4 & \\
\hline Group 1 & $1,182.5$ & 374.5 & 65.7 & 166.3 & 60.5 & 68 & 75.4 & 32.9 & 78.4 & 28.7 & 13.7 & 56.9 \\
\hline Group 2 & 44.0 & 30.1 & 2.5 & 5.3 & 5.5 & 2.2 & 0 & 0 & 0 & 2.9 & 3.0 & 5.5 \\
\hline Group 3 & 313.4 & 250.0 & 16.1 & 44.5 & 28.2 & 17.2 & 14.9 & 18.7 & 13.9 & 9.1 & 9.5 & 16.0 \\
\hline Group 4 & 307.2 & 388.3 & 14.7 & 52.5 & 86.9 & 16.1 & 4.1 & 5 & 4.3 & 9.4 & 9.4 & 18.8 \\
\hline
\end{tabular}

Note: ${ }^{\mathbf{1} G r o u p ~ 1: ~ F r e s h / m i n i m a l l y ~ p r o c e s s e d ~ f o o d ; ~ G r o u p ~ 2: ~ P r o c e s s e d ~ C o o k i n g ~ I n g r e d i e n t s ; ~ G r o u p ~ 3: ~ P r o c e s s e d ~ F o o d ; ~ G r o u p ~ 4: ~ U l t r a-P r o c e s s e d ~}$ Food (according to Brasil [4]; Monteiro et al. [6]). SD: Standard Deviation; AVG: Average.

Table 5. Association between anthropometric variables, dietary intake according to degree of food processing ${ }^{1}$ and age group of assessed women surviving breast cancer. Fortaleza (CE), 2018.

\begin{tabular}{|c|c|c|c|c|c|c|c|c|}
\hline \multirow{2}{*}{$\begin{array}{l}\text { Anthropometric } \\
\text { variables }\end{array}$} & \multicolumn{2}{|c|}{$\begin{array}{l}\text { Fresh/minimally } \\
\text { processed food }\end{array}$} & \multicolumn{2}{|c|}{ Processed food } & \multicolumn{2}{|c|}{ Processed Ingredients } & \multicolumn{2}{|c|}{ Ultra-processed food } \\
\hline & $<60$ years & $\geq 60$ years & $<60$ years & $\geq 60$ years & $<60$ years & $\geq 60$ years & $<60$ years & $\geq 60$ years \\
\hline IMC & $\begin{array}{c}-0.07 \\
(p=0.378)\end{array}$ & $\begin{array}{c}-0.07 \\
(p=0.642)\end{array}$ & $\begin{array}{c}0.00 \\
(p=0.969)\end{array}$ & $\begin{array}{c}-0.04 \\
(p=0.805)\end{array}$ & $\begin{array}{c}0.10 \\
(p=0.214)\end{array}$ & $\begin{array}{c}-0.02 \\
(p=0.891)\end{array}$ & $\begin{array}{c}0.08 \\
(p=0.291)\end{array}$ & $\begin{array}{c}0.07 \\
(p=0.678)\end{array}$ \\
\hline WC & $\begin{array}{c}0.01 \\
(p=0.905)\end{array}$ & $\begin{array}{c}-0.01 \\
(p=0.967)\end{array}$ & $\begin{array}{c}0.02 \\
(p=0.805)\end{array}$ & $\begin{array}{c}-0.16 \\
(p=0.300)\end{array}$ & $\begin{array}{c}-0.03 \\
(p=0.702)\end{array}$ & $\begin{array}{c}-0.06 \\
(p=0.685)\end{array}$ & $\begin{array}{c}0.02 \\
(p=0.804)\end{array}$ & $\begin{array}{c}0.12 \\
(p=0.440)\end{array}$ \\
\hline WHR & $\begin{array}{c}0.07 \\
(p=0.364)\end{array}$ & $\begin{array}{c}0.00 \\
(p=0.978)\end{array}$ & $\begin{array}{c}0.02 \\
(p=0.786)\end{array}$ & $\begin{array}{c}-0.07 \\
(p=0.676)\end{array}$ & $\begin{array}{c}-0.07 \\
(p=0.396)\end{array}$ & $\begin{array}{c}-0.12 \\
(p=0.441)\end{array}$ & $\begin{array}{c}-0.07 \\
(p=0.369)\end{array}$ & $\begin{array}{c}-0.02 \\
(p=0.910)\end{array}$ \\
\hline
\end{tabular}

Note: ${ }^{1}$ According to Brasil [4]; Monteiro et al. [6]

BMI: Body Mass Index; WC: Waist Circumference; WHR: Waist/Hip Ratio.

food consumption ( $p>0.05$ ), with a predominance of fresh/minimally processed foods. Correlation between anthropometric variables, food intake and age range is shown in Table 5. No correlation was observed between food consumption according to the degree of food processing and the nutritional status.

\section{DISCUSSION}

The study detected a high prevalence of overweight patients and, in the dietary evaluation, a consumption of about $1 / 3$ of processed and ultra-processed foods contributing to the total energy intake was observed, regardless of age group.

Breast cancer occurred in relatively young women. Although it is reported that about $75 \%$ of the disease cases are diagnosed in women over 50 years of age, statistics indicate an increased incidence in young women $[13,14]$. Although smoking and alcoholism are also risk factors for cancer disease and its relapse [2], their incidence was low in this study. However, other morbidities were present, especially hypertension and type 2 diabetes Mellitus, which, like overweight and physical inactivity, are hazard factors for breast cancer $[15,16]$.

A recurring concern in breast cancer survivors is the diagnosis of other diseases such as hypertension, diabetes and others. Chronic medications use is also an issue. Reports indicate that 
drugs for the treatment of hypertension and diabetes have been associated with changes in body composition and food intake [17-20]. Studies evaluating the effect of metformin use on patients show improvement in satiety, eating behavior, and modulation of metabolic response to nutrient intake [18-20]. Although this relationship was actually observed, such associations were not the object of the present study.

Patient anthropometric data showed that most of the patients exhibited high WC and WHR, indicating excess abdominal adiposity. High weight is one of the risk factors for breast cancer, especially in postmenopausal women [2], maybe due to overexposure of the breast epithelium to different bioactive substances produced by the adipose tissue [21]. This study population review showed that older patients exhibited a lower prevalence of overweight $(p=0.003)$, although the proportion of obese women was higher in this age group (age $\geq 60$ years).

Consumption of foods with a high degree of processing has been increasing gradually in the population, as shown by a few studies conducted in the USA, Canada, New Zealand, the United Kingdom and Brazil where the intake of ultra-processed food products contributes from $25,00 \%$ to $61.7 \%$ to the total daily energy consumption [22-26].

Louzada et al. [27], conducted an investigation to determine Brazil's diet nutritional quality, in which 32,898 Brazilians were assessed. The authors found an average daily energy intake per capita of $1896 \mathrm{kcal}$, with $58.1 \%$ provided by fresh or minimally processed food, $10.9 \%$ by processed culinary ingredients, $10.6 \%$ by processed food and $20.4 \%$ by ultra-processed food. In the present study, the contribution of processed and ultra-processed food was, respectively, $18.7 \%$ and $14.2 \%$, for women under 60 years of age and $16.1 \%$ and $14.7 \%$ for elderly women, therefore within the range reported in the studies mentioned above [22-26]. Increased consumption of these foods may be associated with the onset of different diseases, since ultra-processed foods most of the times have a high fat content, simple carbohydrates, sodium and high energy density, as well as a low amount of fiber, vitamins and minerals [28-31].

There is a gap in the literature regarding the tolerated ingestion level of processed and ultra-processed food, which could lead to a higher risk of diseases or a worse control of such diseases. This gap is found both in the GAPB $[4,6]$ and in the WCRF/AICR report [2].

In the case of ultra-processed food, it should be understood that the word "avoid" that appears in the GAPB $[4,6]$ means not to ingest such food under any circumstances; however, in the case of processed food, the word "limit" does not help to allow a science-based set up of thresholds. The quantitative interpretation is even more difficult in the WCRF/AICR [2], because these Bodies do not use the processed and ultra-processed terms, but "fast foods" and "other processed foods", recommending to "restrict" intake, but only of those foods high in fat, starch and sugar.

Thus it was not possible to evaluate whether the daily consumption of processed and ultraprocessed foods of about $1 / 3$ of the total caloric contribution is adequate or excessive. In terms of educational initiatives to foster health and disease prevention and control, certain limits should be set out in order to better guide the population in connection with their food selection.

Moreover the National Consensus on Cancer Nutrition [32], which focuses on the treatment of cancer patients, is silent regarding the consumption of ultra-processed food, as there are only generic recommendations to avoid the consumption of processed food such as fast food, sodas and processed meat.

A study performed by Fiolet et al. [5] found that the ingestion of ultra-processed food was associated with increased risk of cancer and especially of breast cancer. The latter association was 
more specifically observed in postmenopausal but not in premenopausal breast cancer. A $10 \%$ increase in the proportion of ultra-processed food in the diet was associated with a significant $12 \%$ increase in the risk of cancer in general, and $11 \%$ in the risk of breast cancer. The authors found no significant association considering the group of processed culinary ingredients or processed food with cancer risk in any anatomical site. On the other hand, higher consumption of fresh/minimally processed food was associated with lower risk of cancer and specifically of breast cancer.

The review performed in this investigation regarding the degree of processed food entering the diet of breast cancer survivors is actually scarce in the literature. In addition, the reviews refer only to the caloric contribution, while in this study the percentage contribution of these food groups in relation to macronutrients was also evaluated. Thus, the larger contribution of processed and ultraprocessed food turned out to be as expected, for carbohydrates and lipids. In the case of proteins, there is a slightly lower contribution of processed foods to the daily intake, but much lower when considering the ultra-processed food, which was intaken by both adult and elderly women.

Despite the findings on the consumption of processed and ultra-processed food, there was no association of such intake with anthropometric markers (BMI, WC and WHR), neither in adult women nor in elderly women. A study by Schiavon et al. [33] showed that while patients with breast cancer who underwent nutritional education intervention developed an increased fruit and vegetable intake and decreased red meat and processed meat intake, there were no changes in their anthropometric measures such as body weight.

Although the study provides relevant information, there are some limitations related to the lack of information about patients' treatment phase and the impact on food intake. Although some studies have observed the effect of chemotherapy on the nutritional status and body composition $[34,35]$, the feeding aspects are not yet clear in the literature [36,37], and the effect of chemotherapy on ultra-processed food consumption has not yet been evaluated. As potentialities of this study it is noteworthy that this is one of the few studies that evaluated the consumption of ultra-processed food in this population, and further research is needed to confirm such results.

Regardless of whether there is a relationship with nutritional status markers or not, the few studies that assessed disease hazards associated with the intake of processed and ultra-processed food show that there is a need to establish the kind of educational initiatives that should be taken on this matter, with view at making feasible decision-making on the frequency and amount of food intake allowed, as is the case with recommendations on alcoholic drinks and salt intake.

\section{CONCLUSION}

Women surviving breast cancer who were assessed, consumed a higher proportion of calorie and macronutrient in their diet, represented by fresh/minimally processed foods; however, there is still about $1 / 3$ contribution represented by processed and ultra-processed foods. There was no association of such consumption with investigated anthropometric markers; however there was a predominance of overweight regardless of age.

So far, there is no theoretical reference that allows affirming that the amount of processed and ultra-processed food consumed represents a hazard for the health of those women. Further studies are required to establish which intake limits for these two food groups are acceptable to ensure good health. 


\section{CONTRIBUTORS}

PC ALVES; HAC SAMPAIO, and EMV HENRIQUES performed the study conception and design, article review and approval of final version. SPM ARRUDA performed the article review. AAF CARIOCA performed the data analysis and interpretation and article review.

\section{REFERENCES}

1. Instituto Nacional do Câncer. Estimativa 2018: incidência de câncer no Brasil. Rio de Janeiro: Inca; 2018. [citado 2018 set. 13]. Disponível em: http://www.inca.gov.br/estimativa/2018/

2. World Cancer Research Fund/American Institute for Cancer Research. Diet, nutrition, physical activity, and cancer: a global perspective. A summary of the third Expert Report. 2018. [cited 2018 Jul 30]. Available from: https://www.wcrf.org/sites/default/files/Summary-third-expert-report.pdf

3. Patterson RE, Marinac CR, Sears DD, Kerr J, Hartman SJ, Cadmus-Bertram L, et al. The Effects of metformin and weight loss on biomarkers associated with breast cancer outcomes. J Natl Cancer Inst. 2018 110:11. http:dx.doi org/10.1093/jnci/djy040

4. Ministério da Saúde (Brasil). Secretaria de Atenção à Saúde. Guia Alimentar para a população brasileira. 2. ed. Brasília: Ministério da Saúde; 2014 [citado 2018 jul 17]. Disponível em: http://189.28.128.100/dab/docs/ portaldab/publicacoes/guia_alimentar_populacao_brasileira.pdf

5. Fiolet T, Srour B, Sellem L, Kesse-Guyot E, Allès B, Méjean C, et al. Consumption of ultra-processed foods and cancer risk: results from NutriNet-Santé prospective cohort. BMJ. 2018;360:k322. http://dx.doi.org/10.1136/ bmj.k322

6. Monteiro CA, Cannon G, Levy RB, Moubarac JC, Jaime P, Martinset AP et al. NOVA: a estrela brilha. World Rev Nutr Diet. 2016 [citado 2018 nov 26]; 7(1-3):28-40. Disponível em: http://www.cookie.com.br/site/ wcontent/uploads/2016/12/ NOVA-Classifica\%C3\%A7\%C3\%A3o-dos-Alimentos.pdf

7. Molina MCB, Benseñor IM, Cardoso LO, Velasquez-Melendez G, Drehmer M, Pereira TSS, et al. Reprodutibilidade e validade relativa do Questionário de Frequência Alimentar do ELSA-Brasil. Cad Saúde Pública. 2013;29(2):379-89 http://dx.doi.org/10.1590/S0102-311X2013000200024

8. Norton K, Olds T. Anthropometrica. Sydney: NSW Press; 1996.

9. World Health Organization. Physical status: The use and interpretation of anthropometry. Geneva: WHO; 1995.

10. World Health Organization. Obesity: Preventing and managing the global epidemic. Report of a WHO consultation, Geneva, 3-5 Jun 1997. Geneva: WHO; 1998.

11. Organización Pan-Americana de la Salud. XXXVI Reunión del Comitê Asesor de Ivestigaciones en Salud - Encuestra Multicêntrica - Salud Beinestar y Envejecimeiento (SABE) en América Latina e el Caribe Informe preliminar. Washington (DC): OPAS; 2001 [citado 2018 ago 24]. Disponible in: http://envejecimiento. csic.es/documentos/documentos/paho-salud-01.pdf

12. Instituto Brasileiro de Geografia e Estatística. Pesquisa de orçamentos familiares 2008-2009: análise do consumo alimentar pessoal no Brasil. Rio de Janeiro: IBGE; 2011 [citado 2018 set 5]. Disponível em: https:// biblioteca.ibge.gov.br/visualizacao/livros/liv50063.pdf

13. Shoshana M, Rosenberg, Ann HP. Management of breast cancer in very young women. Breast. 2015 [cited 2019 Mar 22];24:154-8. Available from: https://www.thebreastonline.com/article/S0960-9776(15)00174-5/ fulltext

14. Eugênio DSG, Souza JA, Chojniak R, Bitencourt AGV, Graziano L, Souza EF. Breast cancer features in women under the age of 40 years. Rev Assoc Méd Bras. 2016 [cited 2018 Oct 27]; 62(8):755-61. Available from: http://www.scielo.br/pdf/ramb/v62n8/0104-4230-ramb-62-08-0755.pdf

15. Sociedade Brasileira de Cardiologia. $7^{\circ}$ Diretriz Brasileira de Hipertensão Arterial. Arq Bras de Cardiol. [citado 2018 out 29];107(3 supl 3). Disponível em: http://publicacoes.cardiol.br/2014/diretrizes/2016/05_ HIPERTENSAO_ARTERIAL.pdf 
16. Diretrizes da Sociedade Brasileira de Diabetes 2017 - 2018. São Paulo: Editora Clannad; 2017 [citado 2018 out 29]. Disponível em: https://www.diabetes.org.br/profissionais/images/2017/diretrizes/diretrizessbd-2017-2018.pdf

17. Sze S, Pellicori P, Kamzi S, Anton A, Clark AL. Effect of beta-adrenergic blockade on weight changes in patients with chronic heart failure. Int J Cardiol. 2018;264:104-12. http://dx.doi.org/10.1016/j.ijcard.2018.03.089

18. Rouquet T, Clément P, Gaigé S, Tardivel C, Roux J, Dallaporta M, et al. Acute oral metformin enhances satiation and activates brainstem nesfatinergic neurons. Obesity (Silver Spring). 2014,22(12):2552-62. http:// dx.doi.org/10.1002/oby.20902

19. Komori T, Yoshida F, Nakamura J, Miyazaki S, Miura H, Iguchi A. Metformin ameliorates treatment of obese type 2 diabetic patients with mental retardation; its effects on eating behavior and serum leptin levels. Exp Clin Endocrinol Diabetes. 2004;112(8):422-8. http://dx.doi.org/10.1055/s-2004-821187

20. Luciano-Mateo F, Hernández-Aguilera A, Cabre N, Camps J, Fernández-Arroyo S, Lopez-Miranda J, et al. Nutrients in energy and one-carbon metabolism: Learning from metformin users. nutrients. 2017 [cited 2019 Jun 13];9:121. http://dx.doi.org/10.3390/nu9020121

21. Bhardwaj P, Au CC, Benito-Martin A, Ladumor H, Oshchepkova S, Moges R, et al. Estrogens and breast cancer: Mechanisms involved in obesity-related development, growth and progression. J Steroid Biochem Mol Biol. 2019;189:161-70. http://dx.doi.org/10.1016/j.jsbmb.2019.03.002

22. Louzada MLC, Martins APB, Canella DS, Baraldi LG, Levy RB, Claro RM, et al. Ultra-processed foods and the nutritional dietary profile in Brazil. Rev Saúde Pública. 2015 [cited 2018 Nov 18];49:38. Available from: http://www.scielo.br/pdf/rsp/v49/0034-8910-rsp-S0034-89102015049006132.pdf

23. Adams J, White M. Characterization of UK diets according to degree of food processing and associations with socio-demographics and obesity: Cross-sectional analysis of UK National Diet and Nutrition Survey (2008-12). Int J Behav Nutr Phys Act. 2015 [cited 2018 Nov 28];12:160. Available from: https://ijbnpa. biomedcentral.com/track/pdf/10.1186/s12966-015-0317-y

24. Moubarac JC, Batal M, Louzada ML, Martinez Steele E, Monteiro CA. Consumption of ultra-processed foods predicts diet quality in Canada. Appetite. 2017;108:512-20. http://dx.doi.org/10.1016/j.appet.2016.11.006

25. Martínez Steele E, Baraldi LG, Louzada ML, Moubarac JC, Mozaffarian D, Monteiro CA. Ultraprocessed foods and added sugars in the US diet: evidence from a nationally representative cross-sectional study. BMJ Open. 2016; [cited 2018 Nov 14];6:e009892. Available from: https://www.ncbi.nlm.nih.gov/ pmc/articles/ PMC4785287/pdf/bmjopen-2015-009892.pdf

26. Luiten CM, Steenhuis IH, Eyles H, Ni Mhurchu C, Waterlander WE. Ultra-processed foods have the worst nutrient profile, yet they are the most available packaged products in a sample of New Zealand supermarketsCORRIGENDUM. Public Health Nutr. 2016;19:539. http://dx.doi.org/10.1017/S1368980015002840

27. Louzada MLDC, Ricardo CZ, Steele EM, Levy RB, Cannon G, Monteiro CA. The share of ultra-processed foods determines the overall nutritional quality of diets in Brazil. Public Health Nutr. 2017 [cited 2018 Nov. 4];21(1):94-102. Available from: https://www.cambridge.org/core/services/aop-cambridge-core/content/ view/5EBC43CD883291F89BCE0B25794FF983/S1368980017001434a.pdf/share_of_ultraprocessed_ foods_determines_the_overall_nutritional_quality_of_diets_in_brazil.pdf

28. Poti JM, Braga B, Qin B. Ultra-processed food intake and obesity: What really matters for health: Processing or nutrient content? Curr Obes Rep. 2017;6(4):420-31. http://dx.doi.org/10.1007/s13679-017-0285-4

29. Julia C, Martinez L, Allès B, Touvier M, Hercberg S, Méjean C, et al. Contribution of ultra-processed foods in the diet of adults from the French NutriNet-Santé study. Public Health Nutr. 2017;21(1):27-37. http://dx.doi. org/10.1017/S1368980017001367

30. Bielemann RM, Motta JVS, Minten GC, Horta BL, Gigante DP. Consumption of ultra-processed foods and their impact on the diet of young adults. Rev Saúde Pública. 2015; 49:28. http://doi.org/10.1590/S0034-8 910.2015049005572

31. Rauber F, Louzada MLC, Steele EM, Millett C, Monteiro CA, Levy RB. Ultra-Processed Food Consumption and Chronic Non-Communicable Diseases-Related Dietary Nutrient Profile in the UK (2008-2014). Nutrients. 2018;10(5):587. http://dx.doi.org/10.3390/nu10050587

32. Instituto Nacional do Câncer. Consenso Nacional de Nutrição Oncológica. Rio de Janeiro: Inca; 2015 [citado 2018 nov 4]. Disponível em: https://www.sbno.com.br/UploadsDoc/consensonacional-de-nutricaooncologica-2-edicao_2015_completo.pdf 
33. SchiavonCC, Vieira FG, Ceccatto V, Liz S, Cardoso AL, Sabel C, et al. Nutrition education intervention for women with breast cancer: Effect on nutritional factors and oxidative stress. J Nutr Educ Behav. 2015; 47(1):2-9. http://dx.doi.org/10.1016/j.jneb.2014.09.005

34. Arpino G, De Angelis C, Buono G, Colao A, Giuliano M, Malgieri S, et al. Metabolic and anthropometric changes in early breast cancer patients receiving adjuvant therapy. Breast Cancer Res Treat. 2015 [cited 2018 Nov 14];154:127-32. Available from: https://www.ncbi.nlm.nih.gov/pmc/articles/PMC4621696/ pdf/10549_2015_Article_3586.pdf

35. Alves PC, Carioca AAF, Sabry MOD, Pinheiro LGP, Oliveira AJN, Tavares NH C, et al. Análise vetorial de bioimpedância elétrica: uma comparação entre sobreviventes de câncer de mama e mulheres saudáveis. Nutr Clín Diet Hosp. 2017;37(2):50-5. http://dx.doi.org/10.12873/372candido

36. Silva EYK, Carioca AAF, Verde SMML, Quintaneiro EC, Damasceno NRT. Effect of chemotherapy on dietary glycemic index and load in patients with breast cancer and their relationships to body fat and phase angle. Nutr Cancer. 2015;67(4),587-93. http://dx.doi.org/10.1080/01635581.2015.1019638

37. Sampaio HAC, Oliveira NM, Sabry MOD, Carioca AAF, Pinheiro LGP. Influência do tipo de terapia antineoplásica sobre marcadores antropométricos e dietéticos em mulheres portadoras de câncer de mama. Rev Bras Cancerol. 2012 [citado 2019 jun 10];58(2):223-30. Disponível em: http://www1.inca.gov.br/rbc/n_58/v02/ pdf/12_artigo_influencia_tipo_terapia_antineoplasica_sobre_marcadores_antropometricos_dieteticos_ mulheres_portadoras_cancer_mama.pdf 